\title{
RAPESEED - A VALUABLE RENEWABLE BIORESOURCE
}

\author{
BOGDAN MARIAN TOFANICA \\ "Gheorghe Asachi" Technical University of Iasi, Faculty of Chemical Engineering and Environmental \\ Protection, Department of Natural and Synthetic Polymers, \\ 73 Prof. dr. docent Dimitrie Mangeron Blvd., 700050 Iasi, Romania \\ Corresponding author: b.m.tofanica@gmail.com
}

Dedicated to the $70^{\text {th }}$ anniversary of the Department of Pulp and Paper, "Cristofor Simionescu" Faculty of Chemical Engineering and Environmental Protection, "Gheorghe Asachi" Technical University of Iasi

The transition to a sustainable economy determines a shift of feedstock for the energy and chemical industries from fossil fuels and petrochemicals to renewable resources. The use of annual plants as a major source of renewable resources represents a valuable alternative both from an economical point of view and from an environmental one. Rapeseed is mainly used as a bioresource for extracting oil and protein for the food industry. Rapeseed stalks represent a valuable source of cellulosic fibres for the paper industry, but their technical use is not put into operation. This review deals with rapeseed as an alternative source of natural chemicals for industries and of cellulosic fibers for the paper industry. The botanical features, including chemical value of rapeseed, are briefly discussed. Also, the basic properties of fibers separated from rapeseed stalks are presented. The utilization potential of rapeseed plant parts is also underlined.

Keywords: rapeseed, chemical value, non-wood fibers, agro-based residues, bioresource

\section{INTRODUCTION}

The pulp and paper industry was one of the most important branches of the booming Romanian chemical industry after World War II. In that period, in Romania, a lot of human and financial capital was invested for the valorisation of annual plants in the pulp and paper industry; researchers acquired rich experience in the field, and their work was recognized worldwide. ${ }^{1}$

The use of non-wood raw materials has been systematically studied at a laboratory scale and at an industrial one. Research has focused on topics such as anatomy and morphology, particularities of chemical composition at the level of the main chemical components, technologies for obtaining pulps, mechanisms of delignification, as well as establishing the paper value of fibres from these raw materials: the behaviour of non-wood cellulosic pulps in the papermaking processes.

Thus, in order to capitalize on non-wood species, extensive studies of native plants and plants originating from different geographical regions have been undertaken: corn stover, ${ }^{2}$ flax and hemp waste, ${ }^{3}$ jute, ${ }^{4,5}$ kenaf, ${ }^{6,7}$ cereal straw - wheat, rye, rice, barley and oat, ${ }^{8-10}$ bagasse, ${ }^{11}$ Romanian reed, ${ }^{12-13}$ Italian reed - Arundo donax L., ${ }^{14}$ sunflower stems. ${ }^{15}$

Nowadays, the increasing demand for biofuels worldwide, tax cuts, subsidies to the agricultural sector, and grants for research programs to obtain energy from renewable resources have encouraged the growth of biofuel and bioliquid production worldwide. ${ }^{16}$ Thus, the "biofuel fever" has overtaken Romania as well, at the level of production of raw materials for manufacture, as the cultivation of vegetable crops has become a profitable business. ${ }^{17}$

In this way, the land areas devoted to crops used for biodiesel production, rapeseed and sunflower, have grown, ${ }^{18}$ the greatest advance in recent years is known to have been made in rapeseed cultivation. In order to support the growth rate of the land area cultivated with rapeseed and to exploit the full potential of the biomass produced, the problem of capitalizing on stalks is still to be solved, knowing that quantitatively, rapeseed stalks represent $50-72 \%$

Cellulose Chem. Technol., 53 (9-10), 837-849(2019) 
of the total biomass, and currently have no economic value.

Under such circumstances, ${ }^{19,20}$ and following the premises developed in one of the first scientific papers on biorefining, ${ }^{21}$ i.e. that (i) all kinds of biomass incorporate the same chemical components, (ii) the macromolecular compounds existing in vegetable biomass incorporate the energy "invested" by the plant to produce it, making their conversion to useful products economical, and (iii) the technology can be modulated depending on the raw material, but also on the desired products, the current manuscript aims to review the use of rapeseed crop for the production of energy carriers, materials, specialty chemicals toward a sustainable bio-based economy.

\section{BOTANICAL FEATURES}

Rapeseed (Fig. 1), known scientifically as Brassica napus L., a bright yellow flowering member of the Brassicaceae family, is a very important and widely cultivated crop throughout the world for the production of animal feed, vegetable oil for human consumption and biodiesel for powering motor vehicles. Also known as rape, oilseed rape or canola, rapeseed has achieved a commodity status worldwide and is used extensively in Europe, Asia and North America. The seed is the valuable, harvested component of the crop. The crop is also grown as a winter-cover crop. It provides good coverage of the soil in winter, and limits nitrogen run-off. Processing rapeseed for oil production provides animal meal as a by-product, which is a highprotein animal feed.

According to the Food and Agriculture Organization of the United Nations (FAO), ${ }^{22}$ rapeseed oil, obtained from crushing rape seeds, was the third leading source of vegetable oil globally in 2008, after soybean oil and palm oil, and also the world's second leading source of protein meal, although only one-fifth of the production of the leading soybean meal. Global rapeseed production has grown rapidly over the past 40 years, rising recently above peanut, cottonseed, and, most recently, sunflower, in worldwide production. This is almost entirely due to plant breeding research, which led to greatly reducing the levels of two anti-nutritional compounds, erucic acid in the oil and glucosinolates in the meal, creating a new, highvalue oil and protein crop.

European production is growing rapidly, with EUROSTAT reporting that 18.4 million tonnes of rapeseed were produced in the 2007 season and 21.8 million tonnes in 2017 , which corresponds to an $18 \%$ growth. In 2018, the European Union, with estimated areas of over 6.7 million hectares and yields of 3.25 tonnes/hectare, outpassed the Americas in oilseed crops. ${ }^{23}$

In Europe, rapeseed is primarily cultivated for the production of vegetable oil for human consumption (as a choice for Europeans to avoid import of genetically modified organism products), and secondarily for animal feed, bio-oil by thermo-chemical conversion and biodiesel. The IENICA - Summary Report for the European Union $^{24}$ suggests that approximately $23 \%$ of the rapeseed grown in the EU is for non-food uses, but differences can be seen in the countries with a developing biodiesel industry. In Germany, France and Czech Republic, for example, rapeseed is the most important agricultural crop and is primarily used for non-food products: the production of biodiesel, oleo-chemicals, lubricants and hydraulic fluids.

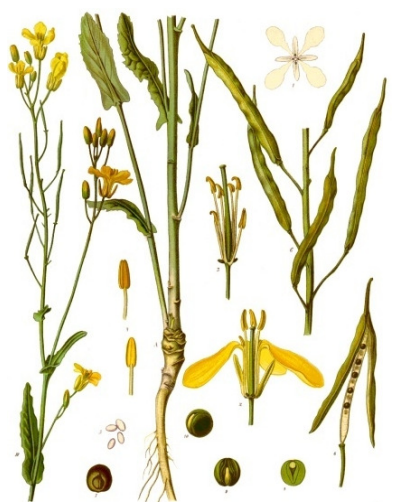

Figure 1: Brassica napus (author: F. E. Köhler, "Köhler's Medizinal-Pflanzen in naturgetreuen Abbildungen mit kurz erläuterndem Texte - Atlas zur Pharmacopoea germanica", 1887) 
Two types of rapeseed can be grown: industrial-quality rapeseed and food-quality rapeseed. The term "industrial rapeseed" does not have any regulatory basis, but refers to any rapeseed with a high content of erucic acid in the oil. For most purposes, the limit is $45 \%$, although higher contents are considered desirable. Foodquality rapeseed is marketed as "canola oil" and generally contains less than 2 percent of erucic acid. $^{25}$

The biomass productivity of winter oilseed rape is due to its growth rate and the duration of the vegetative period. ${ }^{26}$ The total biological yield of winter rapeseed ranges from 10 to 20 metric tons of dry forage/ha with 9 to $12 \%$ protein levels. The world average seed yield of oilseed rape is $1400 \mathrm{~kg} / \mathrm{ha}$. Small holders in India or China harvest only $500-800 \mathrm{~kg} / \mathrm{ha}$, large farms in Canada or Australia 1000-2000 kg/ha, whereas the yields in Europe are $2000-4000 \mathrm{~kg} / \mathrm{ha}$. Due to the high yields in seed oil content (42-48\%), the European Union has been the leading producer of rapeseed oil in recent years. ${ }^{22-23}$

The harvest index of rapeseed, i.e. the proportion of seed dry matter to total biomass (seeds and stalks), varies between approximately 0.28 and 0.50 . Thus, seeds represent $28-50 \%$ of total biomass, and the remaining crop residues, especially stalks, represent $50-72 \%$ of total biomass. In Europe, an economic seed yield of winter oilseed rape between 3 and 4 tons per hectare is normally produced, corresponding to 3 to 10 tons of stalks. ${ }^{27}$

Winter type Brassica napus is the main rapeseed crop in most parts of Europe, in some parts of China and in North America. In geographical areas where winters are mild enough, spring type Brassica napus can be grown in the fall. Spring type rape occupies approximately $50 \%$ of the Canadian rapeseed area and is also grown in Northern Europe, China and India.

Natural rapeseed oil contains erucic acid, which is mildly toxic to humans in large doses, but is used as a food additive in smaller doses. In addition, the rapeseed meal contains high levels of glucosinolates, compounds that at high doses slow down animal growth rates. Recently, low erucic and low glucosinolate types of Brassica napus have been developed. The transition from high erucic to low erucic rapeseed, and the simultaneous rapid growth in the global rapeseed production began in Canada in 1968, with the commercial release of the single zero acid cultivated variety "Oro", followed by several other single low erucic cultivated varieties and the first canola - "Tower" in 1974. Canola (an acronym for "Canada oil, low-acid") was developed in Canada and is a variety of rapeseed with low erucic acid and glucosinolates content. ${ }^{25}$

Today, nearly all rapeseed production in North America and Europe is based on canola - a rapeseed variety suitable for human consumption, while in other areas of the world, both edible and inedible varieties are cultivated. The introduction of low erucic rapeseed is now underway in Asian countries as well, mainly in the leading economies China and India.

The modification in crop quality has created the need for specialized production of industrialized rapeseed products. Improved cultivated varieties for this purpose have been developed in Canada, the United States and now in Europe. Because of the relatively small demand for high erucic oil and, consequently, for industrial rapeseed, in comparison with edible varieties, most plant growers now cultivate exclusively edible assortments.

Rapeseed grows best in mild maritime climates. Historically, the highest rapeseed yields have been produced in England and in the Netherlands, a phenomenon that has more to do with climate and soil conditions than with sophisticated crop management. The growth of rapeseed is most vigorous at temperatures between 10 and $30{ }^{\circ} \mathrm{C}$, with the most favourable values around $20^{\circ} \mathrm{C}$.

Rapeseed is very responsive to high temperatures during the blooming period, even when abundant moisture is available. Long periods of over $30^{\circ} \mathrm{C}$ can result in severe sterility and high yield losses. During the pod-filling period, rapeseed is somewhat more tolerant to high temperatures. The seed oil content, however, is the highest when the seeds mature under low temperatures $\left(10\right.$ to $\left.15^{\circ} \mathrm{C}\right)$. Extended periods of high temperature during the seed-fill period invariably result in low oil contents and poor seed quality. ${ }^{28}$

Rapeseed is derived from two Brassica species, Brassica napus (swede rape) and Brassica rapa (turnip rape). Both species have spring and winter cultivated varieties. The rapeseed oil on the global market comes from these two species and, to a minor extent, from mustards, especially Brassica juncea (brown mustard) and Sinapis alba (yellow mustard). 
Brassica crops may be among the oldest cultivated plants known to humans. In India, Brassica rapa is mentioned in ancient Sanskrit literature from ca. $1500 \mathrm{BC}$ and seeds of Brassica juncea have been found in archaeological sites dating back to ca. 2300 BC. Rapeseed cultivation also has a long history in China. The Chinese word for rapeseed was first recorded approximately 2500 years ago and the oldest archaeological discoveries may date back as far as to approximately $5000 \mathrm{BC} .^{25}$

Historically, Brassica rapa seems to have the widest distribution among Brassica oilseeds. At least 2000 years ago, it was distributed from northern Europe to China and Korea, with the primary center of diversity in the Himalayan region. Brassica napus has probably developed in the area where the wild forms of its ancestral species are sympatric, in the Mediterranean area. ${ }^{25}$ Wild forms of Brassica napus are unknown, so it is possible it originated in cultivation, and the production of oilseed Brassica napus probably started in Europe during the Middle Ages. ${ }^{29}$

In addition to Brassica napus and Brassica rapa, Brassica includes cultivated species $B$. carinata (Abyssinian mustard), B. nigra and $B$. oleracea. The four most widely cultivated species, B. juncea, B. napus, B. oleracea and $B$. rapa, are highly polymorphic, including oilseed crops, root crops and vegetables, such as Chinese cabbage, broccoli and Brussels sprouts.

The "Triangle of U" (Fig. 2) is a theory about the evolution and relationships between members of the plant genus Brassica, developed and first published in 1935 by Woo Jang-choon, a Korean botanist, who made synthetic hybrids between the diploid and tetraploid species and examined how the chromosomes paired in the resulting triploids. The theory is based on the idea that the genomes of three ancestral species of Brassica combined in various configurations to create three of the common contemporary vegetables and oilseed crop species. After methods have been developed to purify DNA from organisms and detailed elucidation of genome structure and function were available, the theory has confirmed that genomic duplication may have preceded the divergence of the cultivated Brassica from one another. ${ }^{30}$

The "Triangle" shows how three of the Brassica species were derived from three ancestral genomes, assigned by the letters AA (Brassica rapa - turnip, Chinese cabbage), BB (Brassica nigra - black mustard) and CC (Brassica oleracea - cabbage, kale, broccoli). Alone, each of these diploid genomes produces a common Brassica species. Initially, these three species existed as isolated relatives and separate species, but because they are closely related, it was possible for them to interbreed. This interspecific breeding allowed for the creation of three new species of tetraploid Brassica. Because they are derived from the genomes of two different species, these hybrid plants are said to be allotetraploid (containing four genomes, derived from two different ancestral species). ${ }^{31}$

\section{CHEMICAL VALUE OF Brassica napus}

A whole crop biorefinery for Brassica napus (Fig. 3) will convert the entire plant (stalk, leaves and seed) into energy, chemicals and materials.

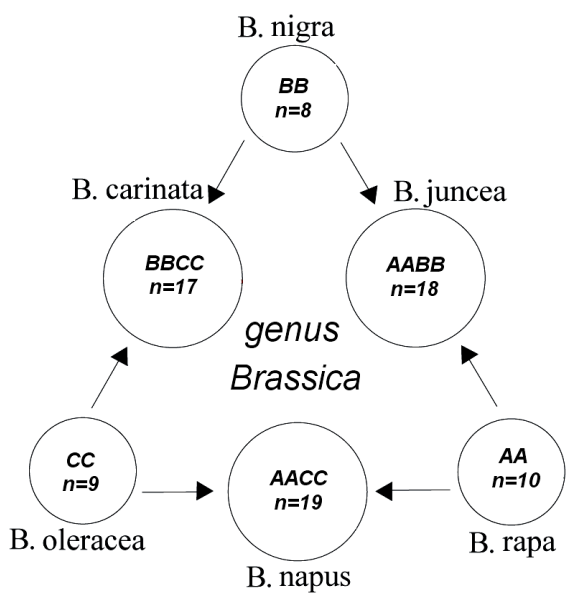

Figure 2: Triangle of $U$ - overview of genetic relationships among various members of the genus Brassica, the origin of the AABB (Indian mustard), AACC (Rapeseed) and BBCC (Ethiopian mustard) species, which have chromosome sets from their $\mathrm{AA}, \mathrm{BB}$ and $\mathrm{CC}$ ancestors 
Rapeseed

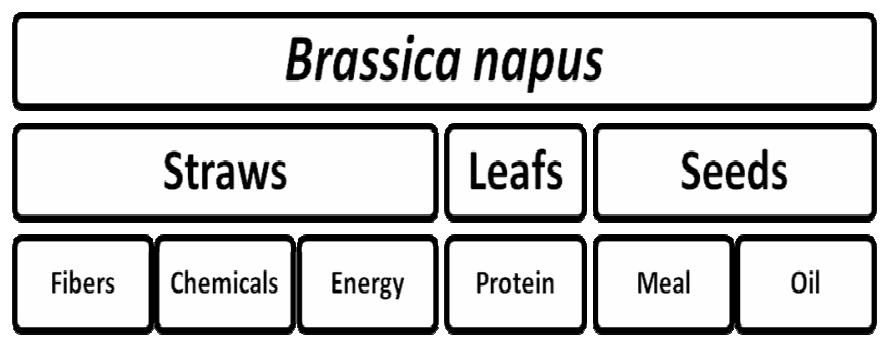

Figure 3: Whole crop biorefinery of Brassica napus

The first step will consist in the separation of the main botanical parts of the crop into different fractions to minimize energy use and labor cost, which can then be used as feedstock for various conventional and new processes. ${ }^{20}$

The seeds may then be processed to produce vegetable oil and a wide variety of products, including bio-ethanol, bio-plastics and meal. The stalk can be processed to fibers, chemicals and energy via various conversion processes, in a lignocellulosic biorefinery.

The energy balance of winter rapeseed and the assessment of the energy efficiency are based on input and output energy. The energy input, including the consumption of diesel fuel required for field operations, manufacturing processes of mineral fertilizers and pesticides, the energy associated with production and maintenance of machines and energy consumption by machines for transport, ranges from 7.42 to $16.1 \mathrm{GJ} / \mathrm{ha}$. The energy output is based on total aboveground biomass, seeds and stalks, and is calculated by multiplying the dry matter yield and the caloric value of the plant material. It ranges between 174$262 \mathrm{GJ} / \mathrm{ha},{ }^{33}$ at production costs for biomass of $292 €_{134}^{-1} \mathrm{y}^{-1}$ and labour input of 7.2 hours.ha ${ }^{-1} \mathrm{y}^{-}$

\section{Rapeseed oil}

For many years, rapeseed has been used for human consumption, despite the known undesirable effects of the glucosinolates found in rapeseed meal and those of the erucic acid from rapeseed oil, which were considered to be acceptable due to the health benefits of the oil.

By the early 1970s, researchers could develop low erucic acid rapeseed (LEAR) varieties, which also had low glucosinolates content. In 1978, the Western Canadian Oilseed Crushers Association registered these varieties under the name "canola" and in the next years, European plant breeders also developed LEAR varieties, which they nicknamed "double-zero" or "canola-
equivalent".

Well-developed rapeseed seed contains 35 to $45 \%$ oil, depending upon variety and environmental factors. The fatty acid composition of the oil is genetically more variable than probably the composition of any other major vegetable oil. Today's canola oil contains only traces of erucic acid (less than $0.1 \%$ ), 5 to $8 \%$ of saturated fat, 60 to $65 \%$ of mono-unsaturated fats, and 30 to $35 \%$ of poly-unsaturated fats. ${ }^{35} \mathrm{~A}$ summary of the composition of $100 \mathrm{~g}$ canola oil is given in Table 1 - data provided by the U.S. Department of Agriculture. ${ }^{36}$

Canola oil is now widely used as cooking oil, salad oil, and as an ingredient in margarine manufacture. Of all edible vegetable oils widely available today, it has the lowest saturated fat content, making it appealing to health-conscious consumers. Its use in continuous frying and some other industrial uses is somewhat limited by its high linolenic acid content (usually 8 to $12 \%$ ) and, therefore, fairly high oxidation tendency. ${ }^{37,38}$

Cultivated varieties with only 2 to $3 \%$ linolenic acid have also been developed. Nonedible uses of canola oil have been studied fairly extensively and, at present, it is used to some extent in lubricants and hydraulic fluids, especially when there is a significant risk of oil leaking to waterways or to groundwater.

The extraction of vegetable oil from rape seeds can be done mechanically or chemically. The latter uses solvents and is generally applied for biodiesel production, due to its higher yields.

Biodiesel, sometimes called FAME (fatty acid ethyl ester), is a mixture of diesel fuel with oils from rape seeds that have fatty acids transesterified for removal of glycerol. After oil is extracted from rape seeds, it is trans-esterified with methanol, leading to methyl or ethyl esters as products. ${ }^{39}$ Biodiesel is a fuel made from natural renewable resources, which can be used directly 
in conventional diesel engines. Biodiesel has several advantages, compared to diesel produced from fossil precursors, for example, it is degradable, non-toxic, contains no sulfur and releases less emission during combustion. ${ }^{40}$ If we consider that on average one liter of vegetal oil and $10 \%$ methanol are needed to make 1 liter of biodiesel and $350 \mathrm{~g}$ of glycerol, the biofuel production yield of rapeseed is high. ${ }^{41}$ As an alternative to diesel fuel, biodiesel already has its place in the current transportation fuel system and is widely used.

Table 1

Canola oil composition (per $100 \mathrm{~g}$ )

\begin{tabular}{|c|c|c|}
\hline Nutrient & Units & Value \\
\hline \multicolumn{3}{|l|}{ Proximates } \\
\hline Water & $\mathrm{g}$ & 0 \\
\hline Energy & $\mathrm{kJ}$ & 3699 \\
\hline Protein & $\mathrm{g}$ & 0 \\
\hline Total lipid (fat) & $\mathrm{g}$ & 100 \\
\hline Ash & $\mathrm{g}$ & 0 \\
\hline Carbohydrate & $\mathrm{g}$ & 0 \\
\hline Fiber, total dietary & $\mathrm{g}$ & 0 \\
\hline Sugars, total & $\mathrm{g}$ & 0 \\
\hline \multicolumn{3}{|l|}{ Vitamins } \\
\hline Vitamin E (alpha-tocopherol) & $\mathrm{mg}$ & 17.46 \\
\hline Vitamin K (phylloquinone) & $\operatorname{mcg}$ & 71.3 \\
\hline \multicolumn{3}{|l|}{ Lipids } \\
\hline Fatty acids, total saturated & $\mathrm{g}$ & 7.365 \\
\hline Fatty acids, total monounsaturated & $\mathrm{g}$ & 63.28 \\
\hline Fatty acids, total polyunsaturated & $\mathrm{g}$ & 28.14 \\
\hline Fatty acids, total trans & $\mathrm{g}$ & 0.395 \\
\hline Fatty acids, total trans-monoenoic & $\mathrm{g}$ & 0.03 \\
\hline Cholesterol & $\mathrm{mg}$ & 0 \\
\hline Stigmasterol & $\mathrm{mg}$ & 3 \\
\hline Campesterol & $\mathrm{mg}$ & 241 \\
\hline Beta-sitosterol & $\mathrm{mg}$ & 413 \\
\hline
\end{tabular}

For industrial purposes, a high erucic acid rapeseed (HEAR) has been developed. ${ }^{25}$ These cultivated varieties can yield $40 \%$ to $60 \%$ of the total oil recovered as erucic acid. High erucic acid rapeseed oil is used in lubricants, especially where high heat stability is required. Due to its high polarity, uniform molecular size, and long carbon chains, it has greater affinity to metal surfaces and better lubricity than mineral oils. It is easily biodegradable, which makes it especially appealing in environmentally sensitive uses.

Although HEAR oil in many applications is superior to vegetable oils with shorter average fatty acid chain length, such as canola, it can sometimes be replaced by these. The surplus of low erucic oil in the European Union has especially increased the industry's interest in using it instead of HEAR oil. This situation has also increased public interest in promoting the production of industrial rapeseed to lower the surplus of low erucic rapeseed. ${ }^{24}$

\section{Rapeseed meal}

Rapeseed meal, the solid residue remaining after extraction of the oil from the rape seeds, is most commonly preferred in animal feed, because it contains around $10 \%$ oil, $10 \%$ fibres and 16$24 \%$ protein, which rates it among the nutritionally best plant proteins. The gross calorific value (GCV) of rapeseed meal, an important property that indicates the useful energy content, is $24 \mathrm{MJ} / \mathrm{kg}$. The GCV of rapeseed meal, close to that of coal (the GCV of anthracite ranges from 26 to $33 \mathrm{MJ} / \mathrm{kg}$ ), makes it an important source of energy. ${ }^{42}$

Other applications of rapeseed meal are in production of enzymes, mushroom cultivation, 
bio-oil and bio-char, as food source for fish diets. $37,38,43$

In native rapeseed, the seed solids contain more than $100 \mu \mathrm{molg}^{-1}$ of glucosinolates. The hydrolysis products of glucosinolates give their characteristic flavor and its pungency. Some of these products, however, are toxic or at least antinutritional. ${ }^{44}$ Also, many of the glucosinolate derivatives decrease the tastiness of the meal and, consequently, the voluntary uptake of the feed by animals. For these reasons, the use of conventional rapeseed meal has been limited mainly to cattle supplementary protein formulas, and it has relatively low value. ${ }^{45}$

Considering the quality of canola, significant amounts of meal can be used in virtually all animal feeds and economical disposal of the crushing residue is typically not a problem. Since some of the glucosinolates are destroyed in the crushing process, the meal of future canola cultivated varieties will be almost glucosinolatefree and could be used in feed formulas without any special limitations. ${ }^{46}$

\section{Rapeseed stalks}

Theoretically, all plants can be used as a source of cellulose fibers for the paper industry. However, for rapeseed to be considered suitable for production of fiber, it is necessary to accomplish several requirements concerning availability, performance and manufacturing processes to reduce the industry's operational costs, as well as to meet the requirement of raw material.

As a vegetable fiber crop, it must accomplish several technical requirements for processing into adequate pulps. It must be adaptable to practical agricultural methods and produce dry matter and fiber yield at economically attractive levels. There must also be a sufficient supply of good quality raw material for running the process throughout the year in its original form. ${ }^{20}$

The average dry biomass of rape varies from 3 to $10 \mathrm{t} / \mathrm{ha}$, and the stem portion with a slender or stout, hard, long tuberous taproot, often manybranched and up to $1.5 \mathrm{~m}$ tall, is about $20 \%$ of the produced dry biomass and remains in the field after seed harvesting. ${ }^{47}$ Therefore, on average, about 40 million tonnes of rape stalk were produced in 2007 and the major portion of it was burned, creating environment pollution. However, this lignocellulosic biomass can be used in various applications, including composites, pulp and paper, as well as in chemical compounds and charcoal making processes. ${ }^{48}$

The stalk from rapeseed is seldom harvested as fuel. The main reasons for this lie in combustion problems and difficulties in collecting the stalk with sufficiently low moisture after the seeds are harvested. Therefore, the stalk is used in crop rotation to increase the humus content in the soil instead ${ }^{49}$ but also for incorporation, immobilization and transformation of available nitrogen and sulphur to stable organic forms in nutrient-poor soils. ${ }^{50}$

The potential uses of rapeseed stalks that are worth mentioning are the following:

- energy in combined heat and power units; ${ }^{51}$

- hydrocarbons and carbon rich solids by thermo-chemical conversion; $;^{52-55}$

- fermentable sugars and ethanol, ${ }^{56-63}$

- papermaking pulps; ${ }^{64-82}$

- composite materials. ${ }^{83-88}$

Some of the barriers to the economic use of rapeseed crop residue are related to the variable quality of the residue, the cost of collection, and problems in transportation and storage because of high moisture content (10-15\%), irregular shape and sizes, and low bulk density $\left(250-300 \mathrm{~kg} / \mathrm{m}^{3}\right)$. Rapeseed stalk must be gathered, processed and densified after harvest in order to facilitate handling, transportation and usage in an efficient manner throughout the year in its original form. ${ }^{89}$

It has been shown that non-wood species have high biomass production capacity and the pulp yields have, in most cases, been higher than those from wood species. Rapeseed shows a very attractive biomass production yield (as presented in Table 2) and produces more usable fiber per land area than trees. ${ }^{90}$

The results of morphological studies and chemical composition analyses showed that rape stalk contained short fibers with similar morphological properties to those of other common non-wood fibers, and that its lignin content was comparable to that of other non-wood papermaking fiber resources. ${ }^{68,91}$

Table 3 shows the average cellulose contents for a wide variety of plant types. On a dry weight basis, most plants consist of approximately 45$50 \%$ cellulose. The cellulose content can vary from almost $90 \%$ for cotton, to about $30 \%$ for rice straw or bamboo. The holocellulose content of rapeseed ranges between $70-75 \%$ (cellulose 40 $44 \%$ ), the lignin content - between 19-21\% and the ash content of $2-3 \% .^{92}$ The chemical composition of rapeseed is comparable with that 
of cereal straws. The amount of cellulose influences the properties of fibers, the economics of fiber production and the utility of the fibers for various conventional and advanced applications. ${ }^{93}$
Fibers with higher cellulose content would be preferable for composites, textiles, paper and other fibrous applications. $^{94}$

Table 2

Annual dry matter and pulp yields of various fiber plants

\begin{tabular}{lcc}
\hline Plant species & $\begin{array}{c}\text { Average dry } \\
\text { matter yield (t/ha) }\end{array}$ & $\begin{array}{c}\text { Pulp yield } \\
(\mathrm{t} / \mathrm{ha})\end{array}$ \\
\hline Rapeseed & 5.5 & 2.2 \\
Wheat straw & 2.5 & 1.1 \\
Rice straw & 3 & 1.2 \\
Common reed & 9 & 4.3 \\
Hemp & 12 & 6.7 \\
Bamboo & 4 & 1.6 \\
Bagasse & 9 & 4.2 \\
Kenaf & 15 & 6.5 \\
Softwood (coniferous) & 1.5 & 0.7 \\
Hardwood (birch) & 3.4 & 1.7 \\
\hline
\end{tabular}

Table 3

Chemical composition of common plant species (percentage of oven-dry components on oven-dry stalks)

\begin{tabular}{lccccc}
\hline \multirow{2}{*}{ Plant species } & \multicolumn{5}{c}{ Chemical composition $(\%)$} \\
\cline { 2 - 6 } & Cellulose & Lignin & Pentosans & Inorganic & Silica \\
\hline Cotton & $85-96$ & $0.7-1.6$ & $1-3$ & $0.8-2$ & - \\
Rapeseed & $40-44$ & $19-21$ & $21-23$ & $2-3$ & $0.2-0.4$ \\
Wheat straw & $29-51$ & $16-21$ & $26-32$ & $4.5-9$ & $3-7$ \\
Rice straw & $28-48$ & $12-16$ & $23-28$ & $15-20$ & $9-14$ \\
Common reed & $44-46$ & $22-24$ & 20 & 3 & 2 \\
Hemp & $57-77$ & $9-13$ & $14-17$ & 0.8 & - \\
Bamboo & $26-43$ & $21-31$ & $15-26$ & $1.7-5$ & 0.7 \\
Bagasse & $32-48$ & $19-24$ & $27-32$ & $1.5-5$ & $0.7-3.5$ \\
Kenaf & $44-57$ & $15-19$ & $22-23$ & $2-5$ & - \\
Softwoods & $40-45$ & $26-34$ & $7-14$ & $<1$ & - \\
Hardwoods & $38-49$ & $23-30$ & $19-26$ & $<1$ & - \\
\hline
\end{tabular}

The lignin content in rape stalks has been found similar to that of hardwood cell walls. The lignin structure appeared to be similar to that found in angiosperm wood, with low syringyl/guaiacyl ratios in the cell walls and this combination of characteristics has raised interest in its potential as a raw material for the pulp and paper industry. ${ }^{95}$ The low lignin content and similitude with hardwood lignin lowers the requirement of chemicals for the delignification of this raw material and for its further processing with a view to enhancing fiber properties by means of chemical or mechanical modification, thus, the production of rape fibers leads to less severe environmental impacts. Conventional methods used in wood fiber separation may very well be employed in the manufacture of rape fibers for various applications. ${ }^{86}$
As an alternative to classical pulping processes, organosolv processes, using organic solvents as delignifying agents, are suitable for pulping rape stalks and have many advantages, such as allowing to obtain pulp with higher hemicellulose levels, less cellulose degradation, higher yield, lower residual lignin content, higher brightness and good strength. The quality of organosolv pulps is better than that of corresponding kraft pulps. The pulp produced is easy to bleach and the yield after bleaching is sometimes higher than the yield of kraft pulp. ${ }^{96}$

Fiber length and width are very important parameters for comparing different species of agro-fibers. A high aspect ratio (length/width ratio) is essential in paper manufacturing, as it gives an indication of the strength properties of the final product. In many cases, there is wide 
variation in both length and width of different fibers. ${ }^{97}$ The length and width of common annual plant fibers and wood fibers are shown in Table 4. The length and diameter of cellulosic fibers from rapeseed stalks are very similar to those of fibers

Table 4

extracted from hardwoods. Therefore, rapeseed fibers can replace wood fibers in a variety of composites, paper and paperboard products, with or without mechanical pretreatments ${ }^{32,98}$ of the rape stalks.

Length and width of common annual plant fibers and wood fibers

\begin{tabular}{lccccc}
\hline \multirow{2}{*}{ Plant species } & \multicolumn{2}{c}{ Fiber length $(\mu \mathrm{m})$} & \multicolumn{2}{c}{ Fiber width $(\mu \mathrm{m})$} & \multicolumn{2}{c}{ Ratio length/ } \\
width
\end{tabular}

As rapeseed stalk is a lignocellulosic material, there are two basic procedures to transform it into biofuel:

- thermo-chemical conversion into a high calorific value synthesis gas with subsequent production of various liquid and gaseous fuels through pyrolysis or gasification; ${ }^{99}$

- transformation into products with high content of energy by microbiological fermentation, through the conversion of polysaccharides into alcohols (like bio-ethanol or bio-butanol), or the conversion of digestible plant biomass into bio-gas, which can be then purified to bio-methane. ${ }^{100}$

The production of bio-ethanol from rapeseed stalk requires basic unit operations, including pretreatment of biomass, acid or enzymatic hydrolysis, fermentation/distillation and ethanol recovery. ${ }^{101}$ Basic operations to release sugars for improving alcoholic fermentation include hydrothermal pretreatment, $^{102}$ sulphuric acidcatalyzed pretreatement ${ }^{103}$ and wet oxidation. ${ }^{104}$ Some intermediate products reported are glucose, xylose, biogas, formic and acetic acid.

\section{Rapeseed leaves}

The concept of using leaf protein in food is not new. Over the last 60 years, scientists from several countries have researched the extractability of proteins from leaves and the preparation of leaf protein concentrate.

Leaf protein fractionation is based on the principle that nitrogen-fixing plants contain higher levels of protein than can be used by ruminant animals and that non-ruminants cannot consume the volume of leaves necessary to meet their protein needs. The high protein content of these plants allows partial removal of the protein for non-ruminant use and the subsequent use of the remainder of the plant by ruminants.

Desirable characteristics of plants as raw materials for extraction and concentration of leaf protein include high protein content, high dry matter content, readily extractable protein from freshly cut plants, good re-growth potential, ability to fix nitrogen, erect growth for easy mechanical harvesting, non-toxicity and low concentration of anti-nutritional substances. ${ }^{105}$

Leaf protein concentrates prepared from Brassica napus gave excellent results in terms of amino acids contents, comparable to those obtained from tobacco, alfalfa and soybean meal. As an example, the extraction process from Nicotiana tabacum yields six major useful products: fraction 1 - crystalline protein, and fraction 2 - protein, green sludge, green residue, pigments and other bio-organic compounds. ${ }^{106}$ Another potential use for canola leaves is as annual forage for field-raised swine and poultry. Canola can produce 1.0 to 2.0 tons of dry matter per acre in a single season. A study conducted in Kansas found winter rapeseed forage to have crude protein of $21-33 \%$, compared to $24 \%$ for winter wheat foliage. ${ }^{107}$ 


\section{CONCLUSION}

Rapeseed is the third most important source of vegetable oil in the world, after soybean oil and palm oil. Brassica napus crops present considerable potential as a sustainable feedstock for fiber, chemicals, energy, protein, meal and oil production.

Rapeseed oil is the most favored vegetable oil for the manufacture of biodiesel. Rapeseed is the world's second leading source of protein meal, although it represents only one-fifth of the production of the leading soybean meal.

The cellulosic fiber potential of rapeseed is insufficiently exploited in paper manufacture. The high production of rapeseed biomass, its good cellulose content and the suitable properties of its fibers are arguments to bolster research efforts to investigate the opportunity of using these fibers in the pulp and paper industry.

Optimizing logistics and management is still necessary for ensuring the profitability of Brassica napus as energy crop feedstock. Biomass quality remains one of the main challenges for the use of this lignocellulosic biomass in power and heat applications: as proven, delayed harvest systems represent a good opportunity for improved biomass combustion properties and for reducing both fertilization and storage costs.

There is a visible trend that is likely to work in favour of an increased use of rapeseed in the future, in oleochemistry and in other application areas. The development of "Green Technology" with increased emphasis on renewable resources and biodegradability is likely to increase interest in new raw materials, such as rapeseed.

ACKNOWLEDGEMENTS: This paper was realized with the support of BRAIN "Doctoral scholarships as an investment in intelligence" project, financed by the European Social Found.

\section{REFERENCES}

P. Obrocea, V. I. Popa, E. Bobu and D. Gavrilescu, "Școala românească de celuloză și hârtie 1949-1999" [R̛omanian Pulp and Paper School 1949-1999] (in Romanian), Editura Plumb, Bacău, 1999

2 G. Popescu and I. Banciu, Celuloză şi Hârtie, 16, 193 (1967), http://ceprohart.ro/revista.php

3 G. Popescu and O. Constantinescu, Celuloză şi Hârtie, 24, 134 (1975), http://ceprohart.ro/revista.php

4 M. Puiu, N. Brăteanu and L. Cauteș, Celuloză și Hârtie, 43, 13 (1994), http://ceprohart.ro/revista.php

5 M. Puiu and L. Cauteș, Celuloză și Hârtie, 44, 23 (1995), http://ceprohart.ro/revista.php
6 C. Stanciu, A. Gorceac and C. Talașman, Celuloză și Hârtie, 44, 45 (1995), http://ceprohart.ro/revista.php

C. Stanciu, A. Gorceac, C. Talașman and G. Teodorescu, Celuloză și Hârtie, 44, 10 (1995), http://ceprohart.ro/revista.php

8 A. Bakk and G. Popescu, Celuloză și Hârtie, 9, 33 (1960), http://ceprohart.ro/revista.php

9 F. Esanu, G. Popescu, G. Petrea and O. Herșcu, Celuloză şi Hârtie, 10, $249 \quad$ (1961), http://ceprohart.ro/revista.php

${ }^{10}$ F. Talis and G. Popescu, Celuloză și Hârtie, 19, 305 (1970), http://ceprohart.ro/revista.php

11 A.-E.-F. Ahmed, P. Obrocea, S. Petrovan and Cr. Simionescu, Celuloză și Hârtie, 22, 15 (1973), http://ceprohart.ro/revista.php

12 Cr. I. Simionescu and G. Rozmarin, "Chimia Stufului" [Reed Chemistry] (in Romanian), Editura Tehnică, București, 1966

13 P. Obrocea, $\mathrm{PhD}$ Thesis, Polytechnic Institute of Iasi, 1970

${ }_{14} \mathrm{Cr}$. Simionescu and E. Calistru, Celuloză și Hârtie, 10, 268 (1961), http://ceprohart.ro/revista.php

15 G. Popescu, Celuloză și Hârtie, 21, 377 (1972), http://ceprohart.ro/revista.php

16 W. E. Mabee, in "Biofuels", edited by L. Olsson, Springer-Verlag, Berlin, 2007, pp. 329-357

17 M. Marinescu, Magazin agricol, 3, 12 (2011)

18 Ministry of Agriculture and Rural Development (MADR), Vegetable production of the main field crops, accessed September 1, 2019, https://madr.ro/agricultura.html

19 A. E. Pânzariu, PhD Thesis, Gheorghe Asachi Technical University of Iaşi, 2013

20 B. M. Tofanica, PhD Thesis, Gheorghe Asachi Technical University of Iaşi, 2011

${ }^{21}$ Cr. Simionescu, V. Rusan and V. I. Popa, Cellulose Chem. Technol., 21, 3 (1987), http://www.cellulosechemtechnol.ro

22 FAOSTAT Statistics Database - Food and Agriculture Organization of the United Nations, $\begin{array}{llll}\text { accessed } & \text { September } & \text { 1, }\end{array}$ http://www.fao.org/faostat/en/

${ }^{23}$ EUROSTAT - Statistical Commission of the European Union, accessed September 1, 2019, https://ec.europa.eu/eurostat/

24 IENICA - Interactive European Network for Industrial Crops and their Applications, Summary Report for the European Union 2000-2005, Fifth Framework Programme of the European Commission, 2005

25 M. Sovero, in "New Crops", edited by J. Janick and J. E. Simon, Wiley, 1993, pp. 302-307, https://hort.purdue.edu/newcrop/proceedings 1993/V2302.html

26 W. Diepenbrock, Field Crop. Res., 67, 35 (2000), https://doi.org/ 10.1016/S0378-4290(00)00082-4

27 G. W. Rathke, T. Behrens and W. Diepenbrock, Agric. Ecos. Environ., 117, 80 (2006), https://doi.org/10.1016/j.agee.2006.04.006 
28 U. S. Congress, Office of Technology Assessment, "Agricultural Commodities as Industrial Raw Materials", OTA-F-476, Washington, DC: U.S. Government Printing Office, 1991

29 P. L. Raymer, in "Trends in New Crops and New Uses", edited by J. Janick and A. Whipkey, ASHS Press, 2002, pp. 122-126

30 A. H. Paterson, J. E. Bowers, J. C. Estill, T. C. Osborn, J. C. Pires et al., in ISHS - Acta Horticulturae 706: Proceedings of a Joint Meeting of $4^{\text {th }}$ International Symposium on Brassicas and $14^{\text {th }}$ Crucifer Genetics Workshop, edited by Y. P. Lim, International Society for Horticultural Science, 2006, pp. https://doi.org/10.17660/ActaHortic.2006.706.2

31 U. Nagaharu, Jpn. J. Bot., 7, 389 (1935)

32 M. G. Papatheofanous, D. P. Koullas, E. G. Koukios, H. Fuglsang, J. R. Schade et al., Biomass Bioenerg., 8, 419 (1995), https://doi.org/10.1016/09619534(95)00040-2

33 G. W. Rathke and W. Diepenbrock, Eur. J. Agronom., $\quad \mathbf{2 4}, \quad 35 \quad$ (2006), https://doi.org/10.1016/j.eja.2005.04.003

34 M. de Wit and A. Faaij, Biomass Bioenerg., 34, 188

https://doi.org/10.1016/j.biombioe.2009.07.011

35 V. J. Barthet, Phytochemistry, 69, 411 (2008), https://doi.org/10.1016/j.phytochem.2007.08.016

${ }^{36}$ U. S. Department of Agriculture, Agricultural Research Service (2009), USDA National Nutrient Database for Standard Reference - Release 22, Nutrient Data Laboratory Home Page, accessed September 1, 2019, http://www.ars.usda.gov/ba/bhnrc/ndl

37 U. Thiyam-Holländer, N. A. Eskin and B. Matthäus (Eds.), "Canola and Rapeseed - Production, Processing, Food Quality, and Nutrition”, CRC Press, 2013, https://www.crcpress.com/Canola-andRapeseed-Production-Processing-Food-Quality-andNutrition/Thiyam-Hollander-Eskin-

Matthaus/p/book/9781138199972

38 F. Shahidi (Ed.), "Canola and Rapeseed Production, Chemistry, Nutrition and Processing Technology", Springer Science, 1990, https://www.springer.com/gp/book/9781461367444

39 J. S. Yuan, K. H. Tiller, H. Al-Ahmad, N. R. Stewart and C. N. Stewart Jr., Trends Plant. Sci., 13, 421

(2008),

https://doi.org/10.1016/j.tplants.2008.06.001

40 M. Arshadi and A. Sellstedt, in "Introduction to Chemicals from Biomass", edited by J. Clark and F. Deswarte, John Wiley and Sons Publication, 2008, pp. 249-284, https://doi.org/10.1002/9781118714478.ch7

41 P. Girard and A. Fallot, Energ. Sustain. Dev., 10, $92 \quad$ (2006), https://doi.org/10.1016/S09730826(08)60535-9

42 S. Ucar and A. R. Ozkan, Bioresour. Technol., 99, 8771

(2008),
43 S. Ramachandran, S. K. Singh, C. Larroche, C. R. Soccol and A. Pandey, Bioresour. Technol., 98, 2000 (2007), https://doi.org/10.1016/j.biortech.2006.08.002

44 G. F. Antonious, M. Bomford and P. Vincelli, $J$. Environ. Sci. Health B, 44, 311 (2009), https://doi.org/10.1080/03601230902728476

45 COPA - Canadian Oilseed Processors Association, accessed September 1, 2019, http://copaonline.net

46 Canola Meal - Feed Industry Guide, accessed September 1, 2019, http://www.canolacouncil.org

47 G. S. Banuelos, D. R. Bryla and C. G. Cook, Ind. Crop. Prod., 15, $237 \quad$ (2002), https://doi.org/10.1016\%2FS0926-6690(01)00119-4

${ }^{48}$ F. Karaosmanoglu and E. Tetik, Energ. Source Part A, 21, $503 \quad$ (1999), https://doi.org/10.1080/00908319950014632

${ }_{49}$ S. Bernesson, D. Nilsson and P. A. Hansson, Biomass Bioenerg., 26, $545 \quad$ (2004), http://doi.org/10.1016/j.biombioe.2003.10.003

50 Bhupinderpal-Singha, Z. Rengela and J. W. Bowden, Soil Biol. Biochem., 38, 32 (2006), https://doi.org/10.1016/j.soilbio.2005.03.025

51 C. Gokcol, B. Dursun, B. Alboyaci and E. Sunan, Energ. Policy, 37, $424 \quad$ (2009), https://doi.org/10.1016/j.enpol.2008.09.057

52 G. Luo, F. Talebnia, D. Karakashev, L. Xie, Q. Zhou et al., Bioresour. Technol., 102, 1433 (2011), https://doi.org/10.1016/j.biortech.2010.09.071

53 O. Onay and O. M. Kockar, Biomass Bioenerg., 26, 289 (2004), https://doi.org/10.1016/S09619534(03)00123-5

54 M. E. Sánchez, E. Lindao, D. Margaleff, O. Martínez and A. Morán, J. Anal. Appl. Pyrol., 85, 142 (2009), https://doi.org/10.1016/j.jaap.2008.11.001

55 S. Yaman, Energ. Conv. Manag., 45, 651 (2004), https://doi.org/10.1016/S0196-8904(03)00177-8

56 E. Castro, M. J. Díaz, C. Cara, E. Ruiz, I. Romero et al., Bioresour. Technol,, 102, 1270 (2011), https://doi.org/10.1016/j.biortech.2010.08.057

57 M. J. Díaz, C. Cara, E. Ruiz, I. Romero, M. Moy et al., Bioresour. Technol., 101, 2428 (2010), https://doi.org/10.1016/j.biortech.2009.10.085

58 A. K. Mathew, K. Chaney, M. Crook and A. C. Humphries, Renew. Energ., 36, 2424 (2011), https://doi.org/10.1016/j.renene.2011.01.030

59 A. Zabaniotou, O. Ioannidou and V. Skoulou, Fuel, 87, $1492 \quad$ (2008), https://doi.org/10.1016/j.fuel.2007.09.003

60 S. G. Wi, B. Y. Chung, Y. G. Lee, D. J. Yang and H.-J. Bae, Bioresour. Technol., 102, 5788 (2011), https://doi.org/10.1016/j.biortech.2011.02.031

61 A. E. Pânzariu and T. Măluțan, Cellulose Chem. Technol., $\quad 49, \quad 93 \quad$ (2015), http://www.cellulosechemtechnol.ro/pdf/CCT1(2015)/ p.93-99.pdf

62 A. Svard, E. Brannvall and U. Edlund, Carbohyd. Polym., $\quad$ 133, $179 \quad$ (2015), https://doi.org/10.1016/j.carbpol.2015.07.023 
63 T. S. Jeong, B. H. Um, J. S. Kim and K. K. Oh, Appl. Biochem. Biotechnol., 161, 22 (2010), https://doi.org/10.1007/s12010-009-8898-z

64 F. Potůček and M. Říhová, Cellulose Chem. Technol., $\quad 50, \quad 681 \quad$ (2016), http://www.cellulosechemtechnol.ro/pdf/CCT56(2016)/p.681-688.pdf

65 F. Potůček and M. Ř́hová, Cellulose Chem. Technol., $\quad 51, \quad 871 \quad$ (2017), http://www.cellulosechemtechnol.ro/pdf/CCT910(2017)/p.871-877.pdf

66 F. Potůček and M. Milichovský, Cellulose Chem. Technol., $\quad 45, \quad 23 \quad$ (2011), http://www.cellulosechemtechnol.ro/pdf/CCT12(2011)/p.23-28.pdf

67 R. Housseinpour, A. J. Latibari, R. Farnood, P. Fatehi and S. J. Sepiddehdam, IAWA J., 31, 457 (2010), https://doi.org/10.1163/22941932-90000035

68 B. M. Tofanica, E. Cappelletto, D. Gavrilescu and K. Müller, J. Nat. Fibers, 8, 241 (2011), https://doi.org/10.1080/15440478.2011.626189

69 I. Deykun, V. Halysh and V. Barbash, Cellulose Chem. Technol., 52, $833 \quad$ (2018), http://www.cellulosechemtechnol.ro/pdf/CCT910(2018)/p.833-839.pdf

70 R. Aguado, A. Moral, P. Mutjé and A. Tijero, Cellulose Chem. Technol., 49, 833 (2015), http://www.cellulosechemtechnol.ro/pdf/CCT910(2015)/p.833-839.pdf

71 A. Moral, R. Aguado, A. Tijero, Q. Tarrés, M. Delgado-Aguilar et al., BioResources, 12, 2792 (2017), http://doi.org/10.15376/biores.12.2.2792-2804

72 F. Potůček, M. Ř́hová and B. Gurung, Cellulose Chem. Technol., 50, $489 \quad$ (2016), http://www.cellulosechemtechnol.ro/pdf/CCT34(2016)/p.489-496.pdf

73 B. M. Tofanica and E. Callone, ChemRxiv, (2019), https://dx.doi.org/10.26434/chemrxiv.8206709.v1

74 B. M. Tofanica and A. C. Puitel, Chem. Eng. Commun., 206, 378 (2019), https://doi.org/10.1080/00986445.2018.1494579

75 B. M. Tofanica, A. C. Puitel and D. Gavrilescu, Environ. Eng. Manag. J., 11, 681 (2012), http://www.eemj.icpm.tuiasi.ro/pdfs/vol11/no3/24_756 Tofanica_11.pdf

${ }_{76}$ S. M. M. Mousavi, S. Z. Hosseini, H. Resalati, S. Mahdavi and E. R. Garmaroody, Ind. Crop. Prod., 95, 643

(2017),

https://doi.org/10.1016/j.indcrop.2016.11.033

77 A. Chaker, P. Mutje, M. Rei Vilar and S. Boufi, Cellulose, 21, 4247 (2014), http://doi.org/10.1007/s10570-014-0454-5

78 S. M. M. Mousavi, S. Z. Hosseini, H. Resalati, S. Mahdavi and E. R. Garmaroody, J. Clean Prod., 52, 420

(2013),

https://doi.org/10.1016/j.jclepro.2013.02.016

${ }^{79}$ M. Kiaei, S. Mahdavi, A. Kialashaki, M. Nemati, A. Samariha et al., Cellulose Chem. Technol., 48, 105 (2014),
http://www.cellulosechemtechnol.ro/pdf/CCT12(2014)/p.105-110.pdf

${ }^{80}$ F. Potůček, B. Gurung and K. Hájková, Cellulose Chem. Technol., 48, $683 \quad$ (2014), http://www.cellulosechemtechnol.ro/pdf/CCT78(2014)/p.683-691.pdf

${ }^{81}$ B. M. Tofanica, A. C. Puitel and D. Gavrilescu, The Bulletin of the Polytechnic Institute from Iaşi, Chemistry and Chemical Engineering Section, Tome 57 (3), 127 (2011).

82 B. M. Tofanica and D. Gavrilescu, Bull. Polytech. Inst. Iaşi, Chem. Chem. Eng., 57, 51 (2011), http://www.bipcic.icpm.tuiasi.ro/2010-

2015.html\#2011_2

${ }^{83}$ H. Yousefi, Waste Manag., 29, 2644 (2009), https://doi.org/10.1016/j.wasman.2009.06.018

${ }^{84}$ D. Paukszta, Fiber. Text. East Eur., 13, 90 (2005), http://www.fibtex.lodz.pl/en9,home_page.html

85 S. Borysiak and D. Paukszta, Mol. Cryst. Liq. Cryst., $\quad 484, \quad 379 \quad$ (2008), https://doi.org/10.1080/15421400801901464

86 D. Gavrilescu, B. M. Tofanica, A. C. Puitel and P. V. Petrea, Environ. Eng. Manag. J., 8, 429 (2009), http://www.eemj.icpm.tuiasi.ro/pdfs/vol8/no3/12_D_G avrilescu.pdf

87 A. C. Puitel, B. M. Tofanica and D. Gavrilescu, Environ. Eng. Manag. J., 11, 651 (2012), http://www.eemj.icpm.tuiasi.ro/pdfs/vol11/no3/20_750 _Puitel_11.pdf

$\overline{88}$ A. C. Puitel, B. M. Tofanica, D. Gavrilescu and P. V. Petrea, Cellulose Chem. Technol., 45, 265 (2011), http://www.cellulosechemtechnol.ro/pdf/CCT3-

4(2011)/p.265-274.pdf

${ }^{89}$ P. Adapa, L. Tabil and G. Schoenau, Biosyst. Eng., 104, 335 (2009), https://doi.org/10.1016/j.biosystemseng.2009.06.022

90 K. Saijonkari-Pahkala, Academic Dissertation, University of Helsinki, Finland, 2001, https://doi.org/10.23986/afsci.5707

91 J. S. Han and J. S. Rowell, in "Paper and Composites from Agro-Based Resources", edited by R. M. Rowell, R. A. Young, J. Rowell, CRC Press, 1996, pp. 83-134, https://www.crcpress.com/Paper-andComposites-from-Agro-Based-Resources/Rowell-

Rowell/p/book/9781566702355

92 F. Karaosmanoglu, E. Tetik, B. Gurboy and I. Sanli, Energ. Source Part A, 21, 801 (1999), https://doi.org/10.1080/00908319950014353

93 D. Belosinschi and B. M. Tofanica, Cellulose, 25, 897 (2018), https://doi.org/10.1007/s10570-018-16523

94 N. Reddy and Y. Yang, Trends Biotechnol., 1, 22 (2005), https://doi.org/10.1016/j.tibtech.2004.11.002

95 B. W. Evans, C. E. Snape and M. C. Jarvis, Phytochemistry, $\quad$ 63, $765 \quad$ (2003), https://doi.org/10.1016/S0031-9422(03)00327-3

96 M. H. Ekhtera, M. Azadfallah, M. Bahrami and J. Mohammadi-Rovshandeh, BioResources, 4, 214 (2009), 
https://bioresources.cnr.ncsu.edu/BioRes_04/BioRes_0 4_1_0214_Ekhtera_AM_Pulp_Paper_Canola_DMF_D EG_412.pdf

97 A. M. Hurter, in Procs. TAPPI Pulping Conference 1988 - Book 1, TAPPI Press, 1988, pp. 139-160, https://www.tappi.org/

98 A. M. Chesca, R. Nicu, B. M. Tofanica, A. C. Puitel, R. Vlase et al., Cellulose Chem. Technol., 52, 645 (2018),

http://www.cellulosechemtechnol.ro/pdf/CCT78(2018)/p.645-653.pdf

99 H. Haykiri-Acma and S. Yaman, Bioresour. Technol., $\quad 99, \quad 237$ (2008), https://doi.org/10.1016/j.biortech.2007.01.001

100 A. Zabaniotou, O. Ioannidou and V. Skoulou, Fuel, 87, 1492

(2008), https://doi.org/10.1016/j.fuel.2007.09.003

101 S. N. Naik, V. V. Goud, P. K. Rout and A. K. Dalai, Renew. Sustain. Energ. Rev., 14, 578 (2010), https://doi.org/10.1016/j.rser.2009.10.003

${ }^{102}$ M. J. Díaz, C. Cara, E. Ruiz, I. Romero, M. Moya et al., Bioresour. Technol., 101, 2428 (2010), https://doi.org/10.1016/j.biortech.2009.10.085
${ }^{103}$ X. Lu, Y. Zhang and I. Angelidaki, Bioresour. Technol., $\quad \mathbf{1 0 0 ,} \quad 3048 \quad$ (2009), https://doi.org/10.1016/j.biortech.2009.01.008

104 A. Petersson, M. H. Thomsen, H. HauggaardNielsen and A.-B. Thomsen, Biomass Bioener., 31, 812

(2007), https://doi.org/10.1016/j.biombioe.2007.06.001

${ }^{105}$ L. Telek, in Plants: The Potentials for Extracting Protein, Medicines, and Other Useful Chemicals Workshop Proceedings, Office of Technology Assessment, 1983, pp. 78-126

106 S. Wildman, in Plants: The Potentials for Extracting Protein, Medicines, and Other Useful Chemicals - Workshop Proceedings, Office of Technology Assessment, 1983, pp. 63-77

${ }^{107}$ E. Oplinger, L. L. Hardman, E. T. Gritton, J. D. Doll and K. A. Kelling, in "Alternative Field Crops Manual", University of Wisconsin Cooperative or Extension Service, Department of Agronomy, 1989, pp. $40-50$ 